\title{
Sleep Issues in Women's Health
}

Editors

KATHRYN ALDRICH LEE

FIONA C. BAKER

\section{SLEEP MEDICINE CLINICS}

www.sleep.theclinics.com

Consulting Editor

TEOFILO LEE-CHIONG Jr

September 2018 • Volume 13 - Number 3 